\title{
Purification and characterization of actinomycins from Streptomyces strain M7 active against methicillin resistant Staphylococcus aureus and vancomycin resistant Enterococcus
}

\author{
Manish Sharma and Rajesh Kumari Manhas ${ }^{*}$ (1)
}

\begin{abstract}
Background: The increased rate of resistance among two highly concerned pathogens i.e. methicillin-resistant Staphylococcus aureus (MRSA) and vancomycin-resistant Enterococcus (VRE) necessitates the discovery of novel anti-MRSA and anti-VRE compounds. In microbial drug discovery, Streptomyces are well known source of two-thirds of natural antibiotics used clinically. Hence, screening of new strains of streptomycetes is the key step to get novel bioactive compounds with antimicrobial activity against drug resistant bacteria.

Results: In the present study, Streptomyces antibioticus strain M7, possessing potent antibacterial activity against different pathogenic bacteria, was isolated from rhizospheric soil of Stevia rebudiana. 16S rRNA sequence of M7 (1418 bp) showed $96.47-100 \%$ similarity with different Streptomyces spp. and the maximum similarity (100\%) was observed with Streptomyces antibioticus NBRC $12838^{\top}$ (AB184184). Phylogenetic analysis using neighbor joining method further validated its similarity with Streptomyces antibioticus NBRC 12838 T (AB184184) as it formed clade with the latter and showed high boot strap value (99\%). Antibacterial metabolites isolated from the fermentation broth were characterized using NMR, FT-IR and LC-MS as actinomycins $V, X_{2}$ and D. The purified actinomycins exhibited potent antibacterial activities against test bacteria viz. B. subtilis, K. pneumoniae sub sp. pneumoniae, $S$. aureus, S. epidermidis, S. typhi, E. coli, MRSA and VRE. Among these actinomycins, actinomycin $\mathrm{X}_{2}$ was more effective as compared to actinomycins $D$ and $V$. The minimum inhibitory concentration values of purified compounds against a set of test bacterial organisms viz. VRE, MRSA, E. coli (S1-LF), K. pneumoniae sub sp. pneumoniae and B. subtilis ranged between 1.95 and $31.25 \mu \mathrm{g} / \mathrm{ml}$.
\end{abstract}

Conclusions: This study demonstrates that actinomycins $\mathrm{V}, \mathrm{X}_{2}$ and $\mathrm{D}$ produced by $\mathrm{S}$. antibioticus strain M7 hold the potential to be used against multidrug resistant bacteria, particularly VRE and MRSA.

Keywords: MRSA, VRE, Actinobacterium, Antibacterial, MIC

\footnotetext{
* Correspondence: rkmanhas@rediffmail.com

Department of Microbiology, Guru Nanak Dev University, Amritsar, Punjab 143005, India
}

(c) The Author(s). 2019 Open Access This article is distributed under the terms of the Creative Commons Attribution 4.0 International License (http://creativecommons.org/licenses/by/4.0/), which permits unrestricted use, distribution, and reproduction in any medium, provided you give appropriate credit to the original author(s) and the source, provide a link to the Creative Commons license, and indicate if changes were made. The Creative Commons Public Domain Dedication waiver (http://creativecommons.org/publicdomain/zero/1.0/) applies to the data made available in this article, unless otherwise stated. 


\section{Background}

Antimicrobial resistance among microbial pathogens is a significant public health issue, as infections caused by multidrug resistant bacteria take the lives of many people in every year all over the world [1]. Among Gram-positive pathogens, a global pandemic of resistant Staphylococcus aureus and Enterococcus species currently pose the biggest threat. A single pathogen i.e. methicillin-resistant Staphylococcus aureus (MRSA), which was first discovered in 1961, has become a major source of nosocomial and community associated MRSA infections [2,3]. Clinical isolates of MRSA have high rate of morbidity and mortality as compared to the methicillin susceptible Staphylococcus aureus [4, 5]. Also, Enterococcus faecium associated with human infections has been developed as multidrug resistant pathogen to vancomycin, ampicillin, and high-levels of aminoglycosides [6, 7].

Vancomycin was the most potent antibacterial drug used against infections caused by MRSA and Enterococcus. However, the first case of MRSA exhibiting resistance to vancomycin was reported from Japanese patient in 1996 [8]. According to CDC (Centers for Disease Control and Prevention) April 2013 report, 30\% of hospital-acquired infections responsible for 1300 deaths per year were due to vancomycin-resistant Enterococcus (VRE) pathogens [9]. While powerful antimicrobial drugs such as synercid, linezolid and daptomycin (lipopeptide) are being used to combat the MRSA and VRE, but some reports showed that these pathogens also have emerged resistance to these effective drugs [10-13]. Because each new antibiotic eventually develops resistance within few years after it is promoted there is always a necessity to find new antimicrobial agents to control antibiotic resistant strains of pathogenic microorganisms.

Recent advances in medical science have sparked to discover the potent therapeutic drugs from the microbial sources. Among microbes, actinobacteria, especially Streptomyces spp. are of immense importance as they are known prolific producers of many novel compounds with diverse biological activities [14-17]. Although, nearly two third of the naturally occurring marketed antibiotics are obtained from Streptomyces spp. but it is just the tip of the iceberg that have been explored [18]. Therefore, to combat with drug resistance and to discover new therapeutic compounds, we need to screen novel streptomycetes from unexplored resources. Keeping this in mind, we isolated an actinobacterium from rhizospheric soil, exhibiting potent antibacterial activity against multidrug resistant bacteria. The present study reports identification of potent actinobacterium as well as purification and characterization of antibacterial compounds, active against MRSA and VRE, produced by it.

\section{Methods}

\section{Sample collection}

The soil sample was collected into a sterile glass screw cap bottle from the rhizosphere of Stevia rebudiana grown in the fields of Palampur, Himachal Pradesh, India.

\section{Test organisms}

Different test bacteria such as Bacillus subtilis (MTCC 619), Escherichia coli (MTCC 1885), Klebsiella pneumoniae sub sp. pneumoniae (MTCC 109), Staphylococcus epidermidis (MTCC 435), Salmonella typhi (MTCC 733), Mycobacterium smegmatis (MTCC 6) and Staphylococcus aureus (MTCC 96) were procured from Microbial Type Culture Collection (MTCC) and Gene Bank, CSIR-Institute of Microbial Technology (IMTECH), Chandigarh, India. Clinical isolates used in the current study viz. E. coli (S1-LF) (resistant to cefotaxime, cefoperazone, ciprofloxacin, rifampicin, and clindamycin), MRSA (resistant to methicillin, teicoplanin, imipenem, and clindamycin) and VRE (resistant to vancomycin, methicillin, teicoplanin, imipenem, and clindamycin) were obtained from local hospitals. All the bacterial cultures were maintained on nutrient agar slants in refrigerator at $4{ }^{\circ} \mathrm{C}$.

\section{Isolation and screening of actinobacteria}

Soil sample was air-dried and given the pre-treatment by heating at $100^{\circ} \mathrm{C}$ for $1 \mathrm{~h}$ to create favorable conditions to accomplish the isolation of actinobacteria. Serial dilution of the treated soil was done up to $10^{-6}$. Aliquots of $0.1 \mathrm{ml}$ from $10^{-2}, 10^{-3}$, and $10^{-4}$ were spread on the surface of SCNA (starch casein nitrate agar) plates. The medium was supplemented with cycloheximide $(50 \mu \mathrm{g} / \mathrm{ml})$ and nalidixic acid $(50 \mu \mathrm{g} / \mathrm{ml})$ to inhibit the growth of fungi and other bacteria, respectively. Plates were then incubated at $28^{\circ} \mathrm{C}$ for $7-$ 21 days. Isolated colonies of actinobacteria were subcultured and purified on SCNA plates. The isolates were preserved in $20 \%$ glycerol at $-20^{\circ} \mathrm{C}$ as stock for future use.

\section{Screening for antibacterial activity}

Primary screening was performed by modified method of Kirby Bauer antibiotic susceptibility test using dual culture technique [19]. In this, $6 \mathrm{~mm}$ plugs of actinobacteria, grown on SCNA plates, were placed on Mueller Hinton Agar medium (MHA) already seeded with test bacteria. The plates were then incubated at $37^{\circ} \mathrm{C}$. The results as zone of inhibition $(\mathrm{mm})$ were obtained after $24 \mathrm{~h}$ of incubation. Isolates which displayed broad spectrum antibacterial activity in ${ }^{\text {primary }}$ screening were subjected to secondary screening using Kirby Bauer agar well diffusion assay [19]. Erlenmeyer flasks $(250 \mathrm{ml})$ containing $50 \mathrm{ml}$ of starch casein nitrate broth were inoculated with 7 days old culture and incubated at $28^{\circ} \mathrm{C}$ for 7 days at $180 \mathrm{rpm}$. The 
MHA plates seeded with test bacteria (OD equivalent to McFarland standard 0.5) were punctured with sterile cork borer to make wells of $6 \mathrm{~mm}$ in size. After addition of culture supernatant $(50 \mu \mathrm{l})$ to each well, the plates were kept in refrigerator for $1 \mathrm{~h}$ for diffusion of active metabolites followed by incubation at $37^{\circ} \mathrm{C}$ for $24 \mathrm{~h}$. The results were observed in terms of inhibition zones around the wells. Out of 12 active isolates, strain M7 was selected based on its strong and broad spectrum antibacterial activity.

\section{Characterization of selected isolate M7 Morphological, physiological and biochemical characterization}

The culture characteristics of strain M7 were determined according to the International Streptomyces Project (ISP) based on the mycelium growth and color, as well as the soluble pigment at $28^{\circ} \mathrm{C}$ for 7 days [20]. Melanin production was detected by growing on ISP6 and ISP7 media. Morphological characteristics of the strain, grown on SCNA at $28^{\circ} \mathrm{C}$ for 4 days, were observed using bright field light and scanning electron microscopy [21]. Physiological and biochemical tests, like growth at different temperatures, $\mathrm{pH}$, salt concentration, and ability to produce different hydrolytic enzymes were performed as per standard protocols [22-24]. Analysis of the sugar components in whole cell hydrolysate and isomer of diaminopimelic acid (DAP) in the cell wall was done according to the method given by Lechevalier and Lechevalier [25]. Assimilation of sugars as carbon sources was studied according to Shirling and Gottlieb [20].

\section{S rRNA gene amplification and phylogenetic analysis}

DNA extraction from isolate M7 was performed using standard protocol described by Marmur [26]. Using genomic DNA as template, $16 \mathrm{~S}$ rRNA gene was amplified using universal primers f27 (5'AGAGTTTGA TCATGGCTCAG 3') and r1492 (5' TACGGCTAC CTTGTTACGACTT-3') [27]. The $1.5 \mathrm{~kb}$ PCR product was then got sequenced from IMTECH, Chandigarh (India). The pairwise sequence alignment of $16 \mathrm{~S}$ rRNA gene sequence was done using ClustalW program and compared with the other related Streptomyces spp. retrieved from EzTaxon server (http:// eztaxon-e.ezbiocloud.net) [15]. Neighbor joining method was used to construct phylogenetic tree based on bootstrap values (1000 replications with MEGA6 software) [28, 29]. The 16S rRNA gene sequence (1418 bp) was deposited in GenBank with accession no. KY548390.

\section{Antibacterial activity profile of Streptomyces strain M7}

Production of active metabolites was done by carrying out fermentation in Erlenmeyer flasks $(250 \mathrm{ml})$, containing $50 \mathrm{ml}$ of production medium (SCN broth) inoculated with $2 \%$ inoculum, at $28^{\circ} \mathrm{C}$ for 10 days under agitation at $180 \mathrm{rpm}$. After every $24 \mathrm{~h}$, the flasks were harvested and the biomass was separated from the culture broth by centrifugation at $10,000 \mathrm{rpm}$ for $20 \mathrm{~min}$. The biomass was dried at $60^{\circ} \mathrm{C}$ for 2 days, weighed and expressed in $\mathrm{mg}$ on dry weight basis. The remaining cell free culture supernatant was used to check the antibacterial activity against test bacterial cultures using agar well diffusion assay.

\section{Extraction of active compounds}

For the recovery of antibacterial metabolites, $96 \mathrm{~h}$ old culture supernatant was extracted twice with different organic solvents viz. ethyl acetate, chloroform, hexane, butanol and diethyl ether using solvent-solvent extraction technique. The separated organic phase was concentrated using the rotary evaporator and redissolved in respective solvent and checked for its antibacterial activity against $B$. subtilis.

\section{Bioautography}

For the analysis of antibacterial metabolites, the ethyl acetate extract was separated by thin layer chromatography (TLC) using ethyl acetate: hexane $(9: 1, v / v)$ as solvent system and the developed chromatogram was observed under UV light and in iodine chamber. TLC strips were then aseptically placed on the surface of MHA already seeded with the test bacterium. Then, the plates were kept at $4{ }^{\circ} \mathrm{C}$ for $1 \mathrm{~h}$ to allow diffusion of the active metabolites from the TLC strips. After that the plates were incubated at $37^{\circ} \mathrm{C}$ for $24 \mathrm{~h}$ and observed for the presence of inhibition zones which indicate the number of active compounds in the solvent extract.

\section{Purification of the active compounds}

To purify the antibacterial compounds, ethyl acetate extract $(150 \mathrm{mg})$ was subjected to silica gel chromatography. The column $(35 \times 1.0 \mathrm{~cm})$ was packed with silica gel (60-120 mesh) using hexane as solvent and eluted step-wise with $100 \%$ hexane, 90:10, 80:20, 70:30, 60:40, $50: 50,40: 60,30: 70,20: 80,10: 90(v / v)$ of hexane: ethyl acetate, $100 \%$ ethyl acetate $(200 \mathrm{ml}$ each $)$ at a flow rate of $2 \mathrm{ml} / \mathrm{min}$. A total of 88 fractions of $25 \mathrm{ml}$ each were collected, concentrated and redissolved in the same solvent ratio from which they were recovered. Fractions showing antibacterial activity against $B$. subtilis were pooled and further purified using size exclusion chromatography with Toyopearl resin HW-40 and methanol as an eluent. A total of 65 fractions were collected and screened for antibacterial activity against $B$. subtilis. Active fractions were further fractionated using preparative RP-HPLC: Shimadzu MicrosorbMV, $100 \mathrm{~mm} \times 10$ $\mathrm{mm} \mathrm{ID,} 10 \mu \mathrm{m}$, at a flow rate of $3 \mathrm{ml} / \mathrm{min}$, with mobile phase of acetonitrile: $\mathrm{H}_{2} \mathrm{O}(55 \%)$ in $30 \mathrm{~min}$ and UV detection at $440 \mathrm{~nm}$. The peaks of the chromatogram 


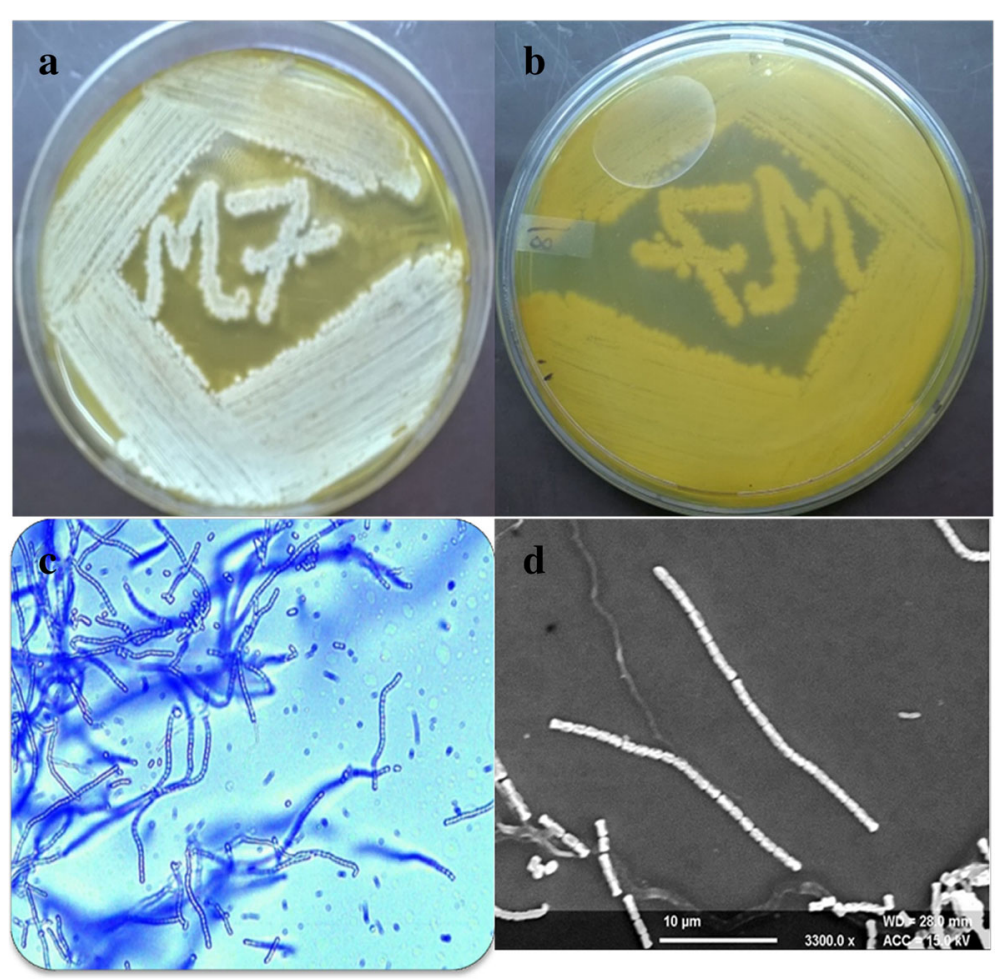

Fig. 1 Cultural characteristics of S. antibioticus strain M7 (a) Aerial Mycelium, (b) Substratum Mycelium, (c) Aerial hyphae bearing straight spore chains under Light Microscope (100X), (d) Scanning electron micrograph (3500X)

were collected by using a fraction collector attached with the HPLC system, concentrated and then screened for antibacterial activity.

\section{Structure elucidation of the purified compounds}

The structures of the bioactive compounds were elucidated using various spectroscopic techniques. Physicochemical properties such as appearance, color, odor and solubility were determined according to the standard procedures [30]. The UV-Visible spectrum was recorded qualitatively on UV- Visible Spectrophotometer (Shimadzu) in the range of $200-800 \mathrm{~nm}$ using chloroform as reference solvent. The mass spectrometry (MS) was done with Bruker MICROTOF II spectrometer, Fourier transformation infrared spectroscopy (FT-IR) was recorded with Perkin-Elmer Spectrum RX-IFTIR spectrophotometer in the range $400-4000 \mathrm{~cm}^{-1}$ and nuclear magnetic resonance (NMR) spectroscopy was recorded in chloroform-d [99.8 atom\% D, containing $0.1 \%(v / v)$ tetramethylsilane $(\mathrm{TMS})]$ at $25^{\circ} \mathrm{C}$ on 500 $\mathrm{MHz}$ AVANCE III Bruker spectrometer equipped with a $5 \mathrm{~mm}$ double channel solution state probe [31, 32].

\section{Antibacterial activity of purified compounds}

The antibacterial activity of the purified compounds was assayed using the standard Kirby-Bauer disc diffusion method. Petri plates containing MHA were swabbed with test bacteria and then discs loaded with $25 \mu \mathrm{g}$ of purified compounds were placed on the surface of the medium followed by compound diffusion at refrigeration temperature for $30 \mathrm{~min}$. The plates were incubated overnight at $37^{\circ} \mathrm{C}$ and the zones of inhibition were measured in millimetres.

\section{Bioautography of purified compounds}

The pure compounds $(30 \mu \mathrm{g})$ were loaded onto precoated TLC plates and separated using ethyl acetatehexane $(9: 1, v / v)$. The dried TLC plates were placed onto the medium seeded with $B$. subtilis. These plates were kept in refrigerator for $1 \mathrm{~h}$ for diffusion. Thereafter, these plates were incubated overnight at $37^{\circ} \mathrm{C}$ for $24 \mathrm{~h}$, observed for clear zones and Retardation factor (Rf) values of purified compounds calculated.

\section{Minimum inhibitory concentration (MIC) of purified compounds}

Minimum inhibitor concentrations of the purified compounds were determined by 96 well microtiter plate dilution assay. The different concentrations of the purified compound $(0.96,1.97,3.95,7.56,15.12$, $31.25,62.5,125 \mu \mathrm{g} / \mathrm{ml}$ ) were prepared in sterile water [33] and added to the test bacteria viz. VRE, MRSA, S1-LF, K. pneumoniae sub sp. pneumoniae and B. subtilis grown to logarithmic phase (between 0.3 to 0.5 


\begin{tabular}{|c|c|}
\hline Characteristics Results & \\
\hline \multicolumn{2}{|l|}{ Cultural Characteristics } \\
\hline Spore mass & Grey \\
\hline Spore chain & Straight \\
\hline Spore shape & Cylindrical \\
\hline Sugar pattern & No sugar \\
\hline Substratum mycelium & Yellow \\
\hline Aerial mycelium & White \\
\hline Diffusible pigment & Yellow \\
\hline Diaminopimelic acid & LL-DAP \\
\hline \multicolumn{2}{|l|}{ Physiological characteristics } \\
\hline Salt tolerance & $5.0 \%$ \\
\hline Temperature tolerance & $20^{\circ} \mathrm{C}$ to $45^{\circ} \mathrm{C}$ \\
\hline pH tolerance & $5-10$ \\
\hline \multicolumn{2}{|l|}{$\begin{array}{l}\text { Production of Melanoid } \\
\text { pigment }\end{array}$} \\
\hline Tyrosine agar medium & + \\
\hline $\begin{array}{l}\text { Peptone Yeast extract } \\
\text { agar medium }\end{array}$ & + \\
\hline \multicolumn{2}{|l|}{ Biochemical characteristics } \\
\hline Indole production & - \\
\hline Methyl red & - \\
\hline $\begin{array}{l}\text { Vogues proskaur } \\
\text { test }\end{array}$ & - \\
\hline Citrate utilization & + \\
\hline Casein hydrolysis & - \\
\hline Catalase test & + \\
\hline Urea hydrolysis & + \\
\hline Esculin hydrolysis & + \\
\hline Starch hydrolysis & + \\
\hline Lipid hydrolysis & + \\
\hline Gelatin hydrolysis & + \\
\hline $\begin{array}{l}\text { Hydrogen sulphide } \\
\text { test }\end{array}$ & + \\
\hline Oxidase test & + \\
\hline $\begin{array}{l}\text { Nitrate Reduction } \\
\text { test }\end{array}$ & - \\
\hline \multicolumn{2}{|l|}{ Utilization of Sugar } \\
\hline Maltose & + \\
\hline D-Glucose & + \\
\hline Sucrose & + \\
\hline Lactose & + \\
\hline Inositol & + \\
\hline D-Xylose & + \\
\hline D-Fructose & + \\
\hline Raffinose & + \\
\hline
\end{tabular}

Table 1 Morphological, Biochemical and Chemotaxonomic Characteristics of Streptomyces antibioticus M7 (Continued)

\begin{tabular}{ll|}
\hline Characteristics Results & + \\
\hline Arabinose & + \\
Starch & + \\
Glycerol & + \\
\hline$=$ Positive, $-=$ Negative
\end{tabular}

OD at $595 \mathrm{~nm})$. Bacterial culture $(100 \mu \mathrm{l})$ was mixed with $100 \mu \mathrm{l}$ of different concentrations of compounds, control blanks contained $100 \mu \mathrm{l}$ of test compound of different concentrations with $100 \mu \mathrm{l}$ of nutrient broth, positive control well consisted of $100 \mu \mathrm{l}$ of bacterial culture and $100 \mu \mathrm{l}$ of Nutrient broth (NB), negative control contained $200 \mu \mathrm{l}$ of NB only and the plates were incubated at $37^{\circ} \mathrm{C}$ and OD was measured at $595 \mathrm{~nm}$ at 24 and $48 \mathrm{~h}$ using ELISA microplate reader (Bio-rad, Model 680XR). MIC values were calculated by comparing the growth in wells containing extract to the growth in control wells and are the lowest concentration that resulted in $90 \%$ inhibition in growth compared to the growth in control well.

\section{Results}

\section{Isolation and screening}

Out of 20 different actinobacteria isolates recovered from the soil, 12 isolates showed activity against one or more test bacteria in the primary screening. Among these, 7 isolates displayed antibacterial activity in fermentation broth with varying degree of inhibition against different test bacteria. Isolate M7 exhibiting potent antibacterial activity against all the test bacteria was selected for further studies.

\section{Identification and characterization of strain M7}

The actinobacterial strain M7 grew well on all the ISP media and SCNA with different cultural characteristics (Additional file 1: Table S1). The strain produced yellow colored diffusible pigment on SCNA (Fig. 1a, b) and brown colored pigment on ISP6 and ISP7 media. Microscopic studies showed the formation of branched substratum mycelium and rectiflexibilis-type spore chains, bearing 25-38 smooth cylindrical spores on aerial mycelium (Fig. 1c, d). Chemotaxonomic analysis of cell wall and whole cell hydrolysates revealed the presence of type 1 cell wall, containing LL-DAP as the diagnostic amino acid and no characteristic sugar. The physiological and biochemical characteristics of the strain are shown in Table 1 . The strain M7 was able to grow at temperature between 25 and $45^{\circ} \mathrm{C}$ (optimum at $28^{\circ} \mathrm{C}$ ), pH 5 to 10 (optimum at pH 7.0) and could tolerate $\mathrm{NaCl}$ upto $5 \%$. M7 strain utilized different tested carbon sources: starch, glycerol, D-glucose, sucrose, 


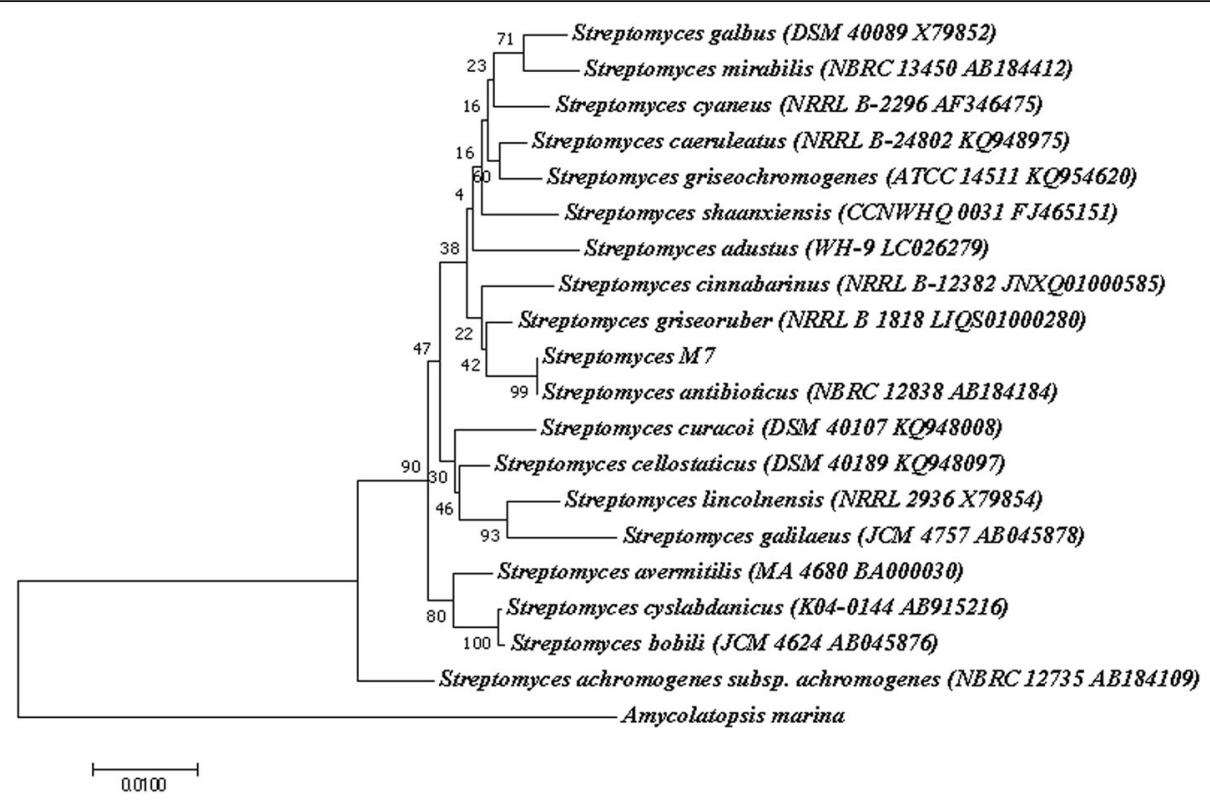

Fig. 2 Phylogenetic tree obtained by neighbor joining analysis of 16S rRNA gene sequences showing the relationship between M7 and related species belonging to genus Streptomyces obtained from EzTaxon database. Numbers on branch nodes are bootstrap values (expressed as percentage of 1000 replications)

lactose, D-fructose, raffinose, inositol, arabinose and Dxylose. The maximum growth was observed on medium containing starch, maltose and sucrose. Biochemical studies showed positive results for production of catalase, oxidase, hydrogen sulfide and citrase, the results for methyl red, voges-proskauer, indole and nitrate reduction were negative. Strain was also able to hydrolyze starch, cellulose, esculin, urea, lipid, and gelatin but did not show casein hydrolysis.

Based on morphological, cultural and chemotaxonomy characteristics, isolate M7 was designated as Streptomyces sp. and was further confirmed by $16 \mathrm{~S}$ rRNA sequencing. Alignment of 16S rRNA sequence of M7 (1418 bp), using EzTaxon database [15], showed $96.47-100 \%$ similarity

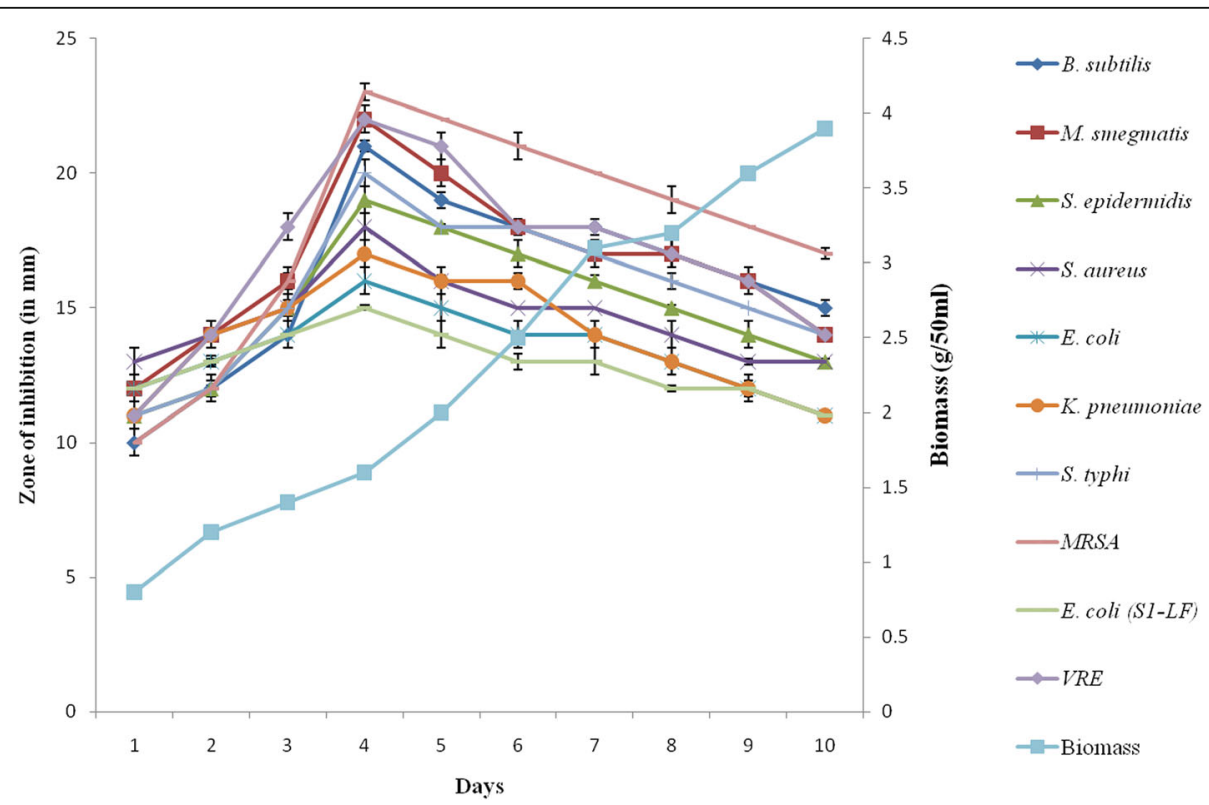

Fig. 3 Growth and antibacterial activity of S. antibioticus strain M7 against test organisms viz. B. subtilis, M. smegmatis, K. pneumoniae sub sp. pneumoniae, S. aureus, S. epidermidis, S. typhi, E. coli, E. coli (S1LF), MRSA and VRE 


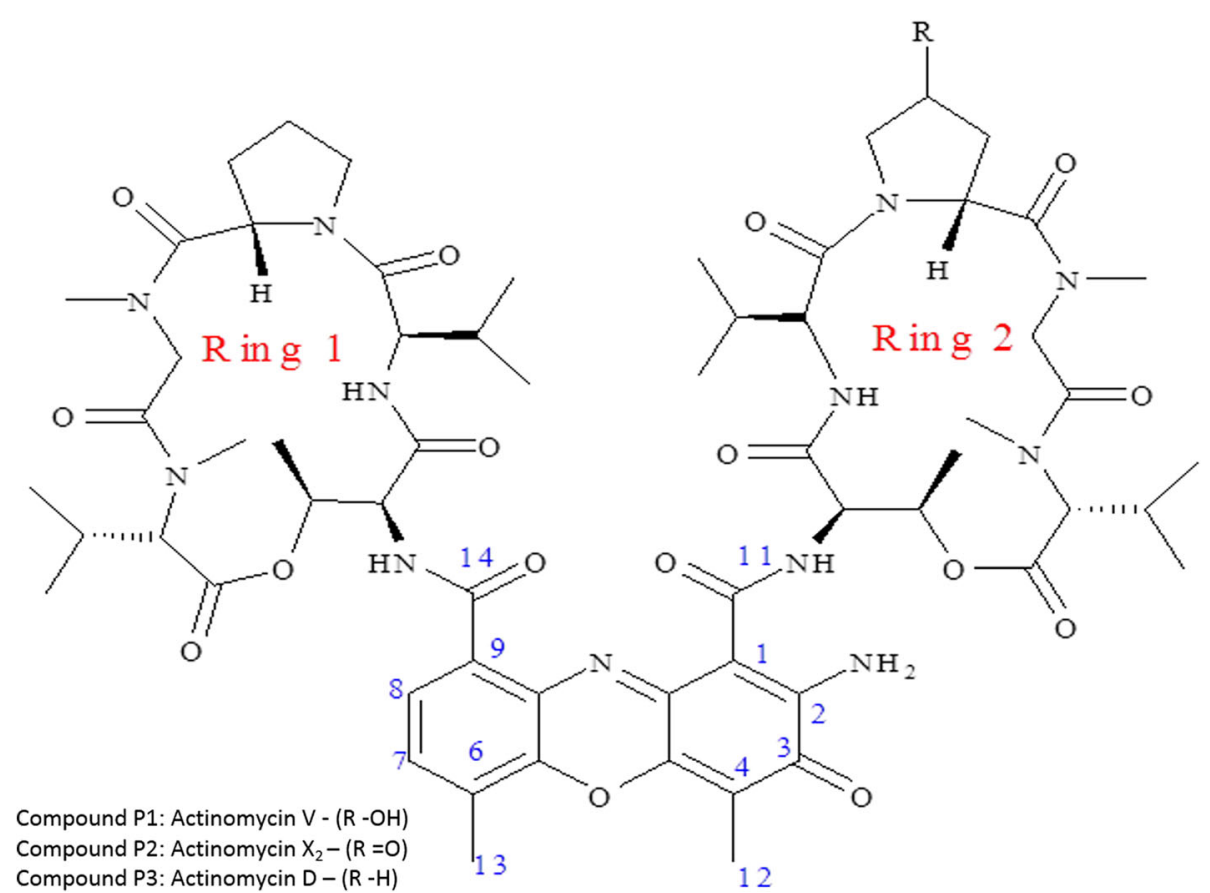

Fig. 4 Chemical structure of Actinomycin V (P1), Actinomycin $X_{2}(P 2)$, Actinomycin D (P3) from S. antibioticus strain M7

with different Streptomyces spp. It showed the maximum similarity (100\%) with Streptomyces antibioticus NBRC $12838^{\mathrm{T}}$ (AB184184) with overlapping of $1417 \mathrm{bp}$ out of 1418 bp. Phylogenetic tree constructed by neighbor joining method further confirmed its similarity with $S$. antibioticus (with high bootstrap values 99\%) (Fig. 2).

\section{Antibacterial activity profile of Streptomyces strain M7}

In vitro bioassay demonstrated strong antibacterial activity of Streptomyces strain M7 against tested bacteria. It showed pronounced inhibition against pathogenic bacteria viz. VRE, MRSA and M. smegmatis with inhibition zones of $23-21 \mathrm{~mm}$. Moderate to weak activity was observed against B. subtilis, K. pneumoniae sub sp. pneumoniae, S. epidermidis, S. typhi, E. coli, S1-LF and $S$. aureus with inhibition zones of $15-20 \mathrm{~mm}$. This suggests that MRSA, VRE and M. smegmatis are more susceptible as compared to other test bacteria. The production of active metabolites in SCN culture broth started after $24 \mathrm{~h}$ of incubation, reached the maximum after $96 \mathrm{~h}$ and declined slightly as the incubation was further extended (Fig. 3).

\section{Recovery, separation and bioautography of bioactive metabolites}

Among all the solvents used, ethyl acetate was found to be the best solvent to achieve the maximum recovery of active metabolites from fermentation broth of pH 5.0. The extracted metabolites in ethyl acetate were concentrated under reduced pressure using rotary evaporator and resulted orange colored dried extract was redissolved in ethyl acetate. Separation of antibacterial metabolites present in crude solvent extract was carried out by thin layer chromatography using ethyl acetate: hexane $(9: 1, v / \mathrm{v})$ as solvent system (Additional file 2: Figure S2a). Bioautography of purified actinomycins also confirmed the three antibacterial compounds with $\mathrm{Rf}$ values of 0.25 (compound P1), 0.52 (compound P2), and 0.48 (compound P3) (Additional file 2: Figure S2b).

\section{Purification of antibacterial compounds from $S$. antibioticus strain M7}

For purification of antibacterial compounds, fermentation was carried out in $\mathrm{SCN}$ broth for 4 days at $28^{\circ} \mathrm{C}$. After 4th day of incubation, culture broth was centrifuged at $10,000 \mathrm{rpm}$ and then extracted twice using ethyl acetate $(1: 2, v / v)$. The obtained orange color crude extract was subjected to silica gel column chromatography for isolation of active compounds. Twenty six fractions (33-58), eluted with hexane: ethyl acetate (10:90, $\mathrm{v} / \mathrm{v}$ ) showed antibacterial activity. These were pooled together based on their similar TLC pattern and concentrated. The pooled fraction was further fractionated on size exclusion chromatography using toyopearl resin HW-40. Nine fractions (27-35) which showed activity were again pooled and finally subjected to semi-preparative HPLC. Individual peaks were collected, and antibacterial activity was detected in two peaks with retention times of 10.524 and $15.443 \mathrm{~min}$ (Additional file 2: Figure S1a). 


\section{a}

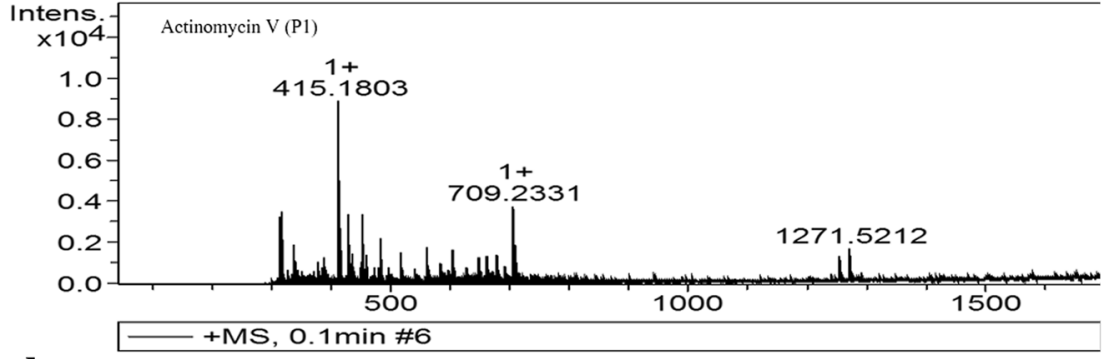

b

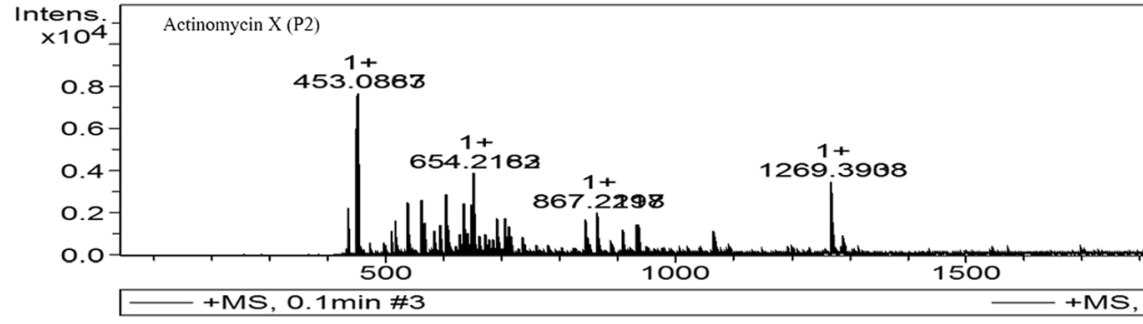

c

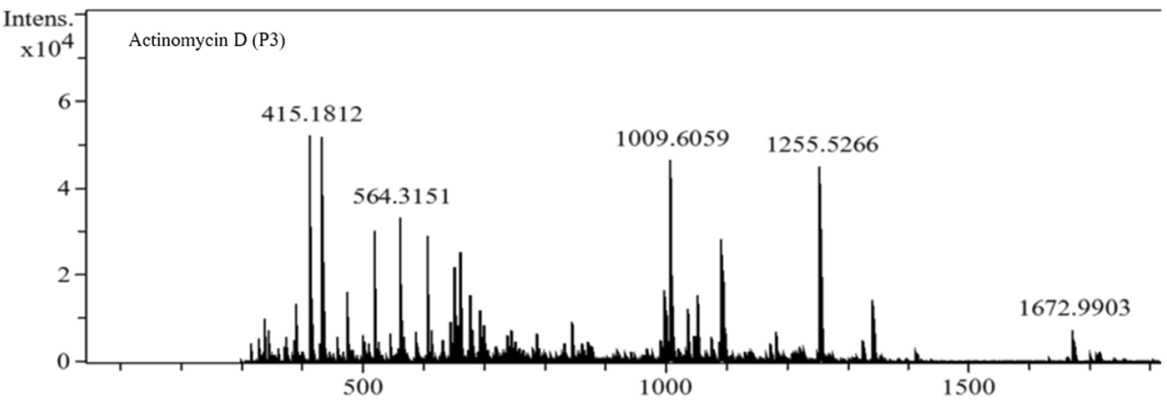

Fig. 5 Mass Spectra of purified compounds from S. antibioticus strain M7 (a) Actinomycin V (P1), (b) Actinomycin $X_{2}(P 2)$, (c) Actinomycin D (P3)

Active peak with retention time of 15.443 was further fractionated by performing HPLC using acetonitrile: water $(95: 5, \mathrm{v} / \mathrm{v})$ as gradient and resulted in separation of compounds P2 and P3 with retention times of 5.814 and 6.548, respectively (Additional file 2: Figure S1b). The collected peaks were further chromatographed using acetonitrile: water (55:45) and single peaks with retention times of $10.628,15.318$, and $15.999 \mathrm{~min}$ were obtained which indicated the purity of the compounds [Additional file 2: Figure S1 (c-e)].

\section{Characterization of the purified antibacterial compounds}

The three active compounds (P1, P2 and P3) were characterized as actinomycins by various spectrometric techniques such as UV-visible, FT-IR, Mass spectrometry and ${ }^{1} \mathrm{H}$ NMR (Fig. 4). All the compounds were soluble in water, chloroform, methanol, ethyl acetate and DMSO. The FT-IR data of these purified compounds confirmed the presence of various functional groups such as primary amine, hydroxyls, alkenes, primary amide and carbonyl groups which are the characteristics of phenoxazone ring. The presence of band range of $2854-2874 \mathrm{~cm}^{-1}$ and $2956-2964 \mathrm{~cm}^{-1}$ showed the symmetrical and asymmetrical $\mathrm{C}-\mathrm{H}$ stretching of $-\mathrm{CH}_{2}$ group, respectively. The Compound P1 (yield: 30 $\mathrm{mg}$ ) was yellow in color, UV $\lambda_{\max } 256,445 \mathrm{~nm}$, Mass Spectrum (TOF, ESI): $m / z\left(\mathrm{M}^{+}\right): 1271.5212$ (Fig. 5a), FT-IR (Additional file 2: Figure S3a). From these data along with ${ }^{1}$ H-NMR [Table 2 and Additional file 3: Figure S4 (a-d)] the compound P1 was identified as Actinomycin V. The Compound P2 was orange in color, yield: $30 \mathrm{mg}$ having $\mathrm{UV} \lambda_{\max }$ 254, $444 \mathrm{~nm}$, Mass Spectrum (TOF, ESI): $m / z\left(\mathrm{M}^{+}\right)$: 1269.3968 (Fig. 5b), FT-IR (Additional file 2: Figure S3b) and ${ }^{1} \mathrm{H}$-NMR spectrum [Table 3 and Additional file 3 : Figure S5 (a-f)] identified the compound as Actinomycin $\mathrm{X}_{2}$. Similarly, the yellow color compound P3 (yield: 40 $\mathrm{mg}$ ) was identified as Actinomycin D on the basis of UV $\lambda_{\max } 256,442 \mathrm{~nm}$, Mass Spectrum (TOF, ESI): $m / z(\mathrm{M})^{+}$: 1255.5266 (Fig. 5c), FTIR (Additional file 2: Figure S3c), ${ }^{1} \mathrm{H}-\mathrm{NMR}$ spectrum [Table 4 and Additional file 3: Figure S6 (a-g)]. The molecular formulae for actinomycins V, $\mathrm{X}_{2}$ and $\mathrm{D}$, calculated on the basis of the NMR, LC-MS and FT-IR data, are $\mathrm{C}_{62} \mathrm{H}_{86} \mathrm{~N}_{12} \mathrm{O}_{17}, \mathrm{C}_{62} \mathrm{H}_{84} \mathrm{~N}_{12} \mathrm{O}_{17}$ and $\mathrm{C}_{62} \mathrm{H}_{86} \mathrm{~N}_{12} \mathrm{O}_{16}$, respectively which are also in agreement with previous findings. 
Table $2{ }^{1} \mathrm{H}$ NMR Data of Purified Actinomycin V

\begin{tabular}{|c|c|c|c|c|}
\hline \multirow{2}{*}{$\frac{\text { Group }}{\text { Phenoxazone }}$} & \multicolumn{2}{|c|}{ Compound P1: Actinomycin V ( $\delta$-value) } & \multicolumn{2}{|c|}{ Actinomycin V (Wang et al. 2017) ( $\delta$-value) } \\
\hline & \multicolumn{2}{|l|}{$7.64(d)$} & \multicolumn{2}{|l|}{$7.64(d)$} \\
\hline & \multicolumn{2}{|l|}{7.37 (d) } & \multicolumn{2}{|l|}{7.35 (d) } \\
\hline & \multicolumn{2}{|l|}{$2.56(\mathrm{~s})$} & \multicolumn{2}{|l|}{$2.54(\mathrm{~s})$} \\
\hline & \multicolumn{2}{|l|}{$2.25(\mathrm{~s})$} & \multicolumn{2}{|l|}{$2.22(\mathrm{~s})$} \\
\hline Amino acids & Ring 1 & Ring 2 & Ring 1 & Ring 2 \\
\hline \multirow[t]{4}{*}{ Threonine } & $4.77(\mathrm{dd})$ & $4.73(\mathrm{dd})$ & $4.81(\mathrm{dd})$ & $4.49(\mathrm{dd})$ \\
\hline & $5.19(\mathrm{~m})$ & $5.24(\mathrm{~m})$ & $5.24(\mathrm{~m})$ & $5.24(\mathrm{~m})$ \\
\hline & $1.27(\mathrm{~s})$ & $1.24(d)$ & $1.28(d)$ & $1.24(\mathrm{~d})$ \\
\hline & $7.37(d)$ & $7.48(d)$ & $7.44(d)$ & 7.50 (d) \\
\hline \multirow[t]{5}{*}{ Valine } & $3.57(\mathrm{dd})$ & $3.55(\mathrm{dd})$ & $3.57(\mathrm{dd})$ & $3.55(\mathrm{dd})$ \\
\hline & $2.17(\mathrm{~m})$ & $2.07(\mathrm{~m})$ & $2.16(\mathrm{~m})$ & $2.12(\mathrm{~m})$ \\
\hline & $0.96(d)$ & $0.94(d)$ & $0.96(d)$ & $0.94(d)$ \\
\hline & $0.74(d)$ & $0.74(d)$ & $0.72(d)$ & $0.74(d)$ \\
\hline & 8.17 (d) & $8.01(d)$ & $8.17(d)$ & $7.91(d)$ \\
\hline \multirow[t]{4}{*}{ Proline } & $5.95(d)$ & $6.02(d)$ & $5.97(d)$ & 6.05 (d) \\
\hline & $1.84(\mathrm{~m}), 2.78(\mathrm{~m})$ & $4.13(\mathrm{~m}), 3.95(\mathrm{~m})$ & $1.84(\mathrm{~m}), 2.78(\mathrm{~m})$ & $4.13(\mathrm{~m}), 3.95(\mathrm{~m})$ \\
\hline & $2.06(\mathrm{~m}), 2.26(\mathrm{~m})$ & $4.70(\mathrm{~m})$ & $2.06(\mathrm{~m}), 2.26(\mathrm{~m})$ & $4.70(\mathrm{~m})$ \\
\hline & $3.83(\mathrm{~m}), 3.77(\mathrm{~m})$ & $3.56(\mathrm{~m}), 3.08(\mathrm{~m})$ & $3.85(\mathrm{~m}), 3.73(\mathrm{~m})$ & $3.56(\mathrm{~m}), 3.08(\mathrm{~m})$ \\
\hline \multirow[t]{2}{*}{ Sarcosine } & $4.62(d)$ & $4.50(d)$ & $4.72(d)$ & 4.55 (d) \\
\hline & $3.63(d)$ & $3.59(d)$ & $3.63(d)$ & 3.59 (d) \\
\hline \multirow[t]{6}{*}{ MethyIValine } & $2.88(\mathrm{~s})$ & $2.88(\mathrm{~s})$ & $2.87(\mathrm{~s})$ & $2.87(\mathrm{~s})$ \\
\hline & $2.70(d)$ & $2.68(d)$ & $2.71(d)$ & 2.67 (d) \\
\hline & $2.78(\mathrm{~m})$ & $2.65(\mathrm{~m})$ & $2.78(\mathrm{~m})$ & $2.64(\mathrm{~m})$ \\
\hline & $0.96(d)$ & $0.94(d)$ & $0.96(d)$ & $0.94(d)$ \\
\hline & $0.74(d)$ & $0.74(d)$ & $0.75(d)$ & $0.74(d)$ \\
\hline & $2.94(\mathrm{~s})$ & $2.91(\mathrm{~s})$ & $2.91(\mathrm{~s})$ & $2.94(\mathrm{~s})$ \\
\hline
\end{tabular}

\section{Antibacterial activity of purified compounds}

The purified compounds exhibited potent antibacterial activity against a range of both Gram negative and Gram positive bacteria viz. B. subtilis, K. pneumoniae sub sp. pneumoniae, S. aureus, S. epidermidis, $S$. typhi, E. coli, S1-LF, MRSA and VRE. In case of MRSA and VRE, the compound P2 (Actinomycin $\mathrm{X}_{2}$ ) was more effective with inhibition zones in the range of 18 and $26 \mathrm{~mm}$ as compared to compound P3 (Actinomycin D) (17 and $25 \mathrm{~mm}$ ) and compound P1 (Actinomycin V) (14 and $24 \mathrm{~mm})$. The compounds showed significant activity against drug resistant strains which are resistant to methicillin (MRSA) $(10 \mu \mathrm{g} / \mathrm{disc})$ and vancomycin $(30 \mu \mathrm{g} /$ disc) $(\mathrm{VRE})$ (Fig. 6, Additional file 1: Table S3).

\section{MIC values of purified compounds}

The MIC values of the purified compounds were determined by 96 well plate method. The Actinomycin
$\mathrm{X}_{2}$ was found to be more potent with lowest MICs as compared to actinomycins $\mathrm{D}$ and $\mathrm{V}$. The MIC values of purified actinomycin $\mathrm{X}_{2}$ against test bacteria ranged between 1.95 and $15.62 \mu \mathrm{g} / \mathrm{ml}$ whereas those for actinomycins $\mathrm{V}$ and $\mathrm{D}$ ranged between 2.25 and $31.25 \mu \mathrm{g} / \mathrm{ml}$, and 2.0 and $15.0 \mu \mathrm{g} / \mathrm{ml}$, respectively. All the three actinomycins were found to be more effective against MRSA and VRE with MICs of 1.95$2.25 \mu \mathrm{g} / \mathrm{ml}$ and $3.5-4.0 \mu \mathrm{g} / \mathrm{ml}$, respectively than against $K$. pneumoniae sub sp. pneumoniae, S1-LF and B. subtilis with MIC values of $15.0-31.5 \mu \mathrm{g} / \mathrm{ml}$, $14.23-15.90 \mu \mathrm{g} / \mathrm{ml}$ and $8.0-15.62 \mu \mathrm{g} / \mathrm{ml}$, respectively, (Additional file 1: Table S3).

\section{Discussion}

The emergence and spread of multidrug resistant bacteria cause an array of health problems due to various interconnected factors, many of which are related to over and misuse of antimicrobial drugs and acquisition of resistance genes [34-36]. The rising levels of antibiotic resistance 
Table $3^{1} \mathrm{H}$ NMR Data of Purified Actinomycin $X_{2}$

\begin{tabular}{|c|c|c|c|c|}
\hline \multirow{2}{*}{$\begin{array}{l}\text { Group } \\
\text { Phenoxazone }\end{array}$} & \multicolumn{2}{|c|}{ Compound P1: Actinomycin $X_{2}$ ( $\delta$-value) } & \multicolumn{2}{|c|}{ Actinomycin $X_{2}$ (Wang et al. 2017) ( $\delta$-value) } \\
\hline & \multicolumn{2}{|l|}{$7.61(d)$} & \multicolumn{2}{|l|}{7.60 (d) } \\
\hline & \multicolumn{2}{|l|}{7.37 (d) } & \multicolumn{2}{|l|}{$7.35(d)$} \\
\hline & \multicolumn{2}{|l|}{$2.56(\mathrm{~s})$} & \multicolumn{2}{|l|}{$2.55(\mathrm{~s})$} \\
\hline & \multicolumn{2}{|l|}{$2.25(\mathrm{~s})$} & \multicolumn{2}{|l|}{$2.24(s)$} \\
\hline Amino acids & Ring 1 & Ring 2 & Ring 1 & Ring 2 \\
\hline \multirow[t]{4}{*}{ Threonine } & $4.55(\mathrm{~m})$ & $4.48(\mathrm{~m})$ & $4.55(\mathrm{~m})$ & $4.48(\mathrm{~m})$ \\
\hline & $5.15(\mathrm{~m})$ & $5.24(\mathrm{~m})$ & $5.15(\mathrm{~m})$ & $5.24(\mathrm{~m})$ \\
\hline & $1.14(d)$ & $1.26(d)$ & $1.14(d)$ & $1.26(d)$ \\
\hline & 7.17 (d) & $7.67(d)$ & 7.17 (d) & 7.67 (d) \\
\hline \multirow[t]{5}{*}{ Valine } & $3.57(\mathrm{dd})$ & $3.71(\mathrm{~m})$ & $3.57(\mathrm{dd})$ & $3.70(\mathrm{~m})$ \\
\hline & $2.10(\mathrm{~m})$ & $2.09(\mathrm{~m})$ & $2.10(\mathrm{~m})$ & $2.09(\mathrm{~m})$ \\
\hline & $0.90(d)$ & $0.89(d)$ & $0.90(d)$ & 0.89 (d) \\
\hline & $1.12(d)$ & $1.15(d)$ & $1.12(d)$ & $1.15(d)$ \\
\hline & 7.68 (d) & $8.21(d)$ & 7.68 (d) & $8.19(d)$ \\
\hline \multirow[t]{4}{*}{ Proline } & $5.96(d)$ & $6.02(d)$ & $5.95(d)$ & $6.05(d)$ \\
\hline & $1.82(\mathrm{~m}), 2.75(\mathrm{~m})$ & $3.85(\mathrm{~m}), 2.23(\mathrm{~m})$ & $1.84(\mathrm{~m}), 2.75(\mathrm{~m})$ & $3.85(\mathrm{~m}), 2.33(\mathrm{~m})$ \\
\hline & \multicolumn{2}{|l|}{$2.25(\mathrm{~m})$} & \multicolumn{2}{|l|}{$2.24(\mathrm{~m})$} \\
\hline & $3.89(\mathrm{~m}), 3.74(\mathrm{~m})$ & $4.55(\mathrm{~m}), 3.89(\mathrm{~m})$ & $3.85(\mathrm{~m}), 3.73(\mathrm{~m})$ & $4.55(\mathrm{~m}), 3.89(\mathrm{~m})$ \\
\hline \multirow[t]{2}{*}{ Sarcosine } & $4.72(d)$ & $4.57(d)$ & $4.72(d)$ & 4.57 (d) \\
\hline & $3.62(d)$ & $3.62(d)$ & 3.62 (d) & $3.62(d)$ \\
\hline \multirow[t]{6}{*}{ MethylValine } & $2.89(\mathrm{~s})$ & $2.90(\mathrm{~s})$ & $2.88(\mathrm{~s})$ & $2.89(\mathrm{~s})$ \\
\hline & $2.68(\mathrm{~m})$ & $2.68(\mathrm{~m})$ & $2.68(\mathrm{~m})$ & $2.68(\mathrm{~m})$ \\
\hline & $2.68(\mathrm{~m})$ & $2.68(\mathrm{~m})$ & $2.68(\mathrm{~m})$ & $2.68(\mathrm{~m})$ \\
\hline & $0.94(d)$ & $0.97(d)$ & $0.94(d)$ & $0.97(d)$ \\
\hline & 0.74 (d) & $0.73(d)$ & $0.74(d)$ & $0.73(d)$ \\
\hline & $2.92(\mathrm{~s})$ & $2.93(\mathrm{~s})$ & $2.92(s)$ & $2.93(\mathrm{~s})$ \\
\hline
\end{tabular}

have complicated the treatment therapy for HAI (health care-associated infections) MRSA and VRE infections [37]. In this biological arm race, humans appear to be helpless as pathogens continue to develop resistance against each new drug introduced in the market. Hence, there is an urgent need to search new antimicrobial agents against these pathogens.

In the light of this, during our research studies to find new antibacterial compounds, a Streptomyces strain, designated M7, possessing potent antibacterial activity against various bacteria including MRSA and VRE was identified as Streptomyces antibioticus. The antibacterial compounds purified from strain M7, belonging to phenoxazone group of chromopeptides, were identified as actinomycins $\mathrm{V}, \mathrm{X}_{2}$ and $\mathrm{D}$ on the basis of their LC-MS, NMR and FTIR spectral data [38-46]. Many Streptomyces spp. viz. Streptomyces MITKK-103, Streptomyces padanus JAU4234, Streptomyces elizabethii, Streptomyces sp. MS449, Streptomyces sp. HUST012, Streptomyces heliomycini are reported to produce actinomycins D, V and $\mathrm{X}_{2}$ simultaneously [40, 41, 47-50]. Recently, Wang et al. (2018) demonstrated the production of two new natural actinomycins, neo-actinomycins $\mathrm{A}$ and $\mathrm{B}$ formed from actinocin chromophore of actinomycin D (by the condensation of actinomycin D with $\alpha$-ketoglutarate and pyruvate), in addition to actinomycin $\mathrm{D}$ and $\mathrm{X}_{2}$ from a marine-derived Streptomyces sp. IMB094 [51].

Actinomycins are cytotoxic compounds which exhibit potential cytotoxicity against various cancer cell lines but low toxicity against normal human cell lines [50]. They are one of the oldest anticancer drugs used in the treatment of various sarcomas. However, antimicrobial activities of actinomycins against pathogenic bacteria, especially MRSA and VRE have gained very little attention. Khieu et al. reported antibacterial activities of actinomycin D (SPE-B5.4) and a new compound (SPE-B11.8) purified from an endophytic Streptomyces sp. HUST012 against a set of test bacteria [E. coli ATCC 25922, K. pneumoniae sub sp. pneumoniae ATCC 13883, methicillin-resistant Staphylococcus epidermidis ATCC 
Table $4{ }^{1} \mathrm{H}$ NMR Data of Purified Actinomycin D

\begin{tabular}{|c|c|c|c|c|}
\hline Group & \multicolumn{2}{|c|}{ Compound P3: Actinomycin D ( $\delta$-value) } & \multicolumn{2}{|c|}{ Actinomycin D (Wang et al.2017) ( $\delta$-value) } \\
\hline \multirow[t]{4}{*}{ Phenoxazone } & \multicolumn{2}{|l|}{$7.60(d)$} & \multicolumn{2}{|l|}{$7.64(d)$} \\
\hline & \multicolumn{2}{|l|}{$7.34(d)$} & \multicolumn{2}{|l|}{7.37 (d) } \\
\hline & \multicolumn{2}{|l|}{$2.53(\mathrm{~s})$} & \multicolumn{2}{|l|}{$2.56(\mathrm{~s})$} \\
\hline & \multicolumn{2}{|l|}{$2.22(\mathrm{~s})$} & \multicolumn{2}{|l|}{$2.25(s)$} \\
\hline Amino acids & Ring 1 & Ring 2 & Ring 1 & Ring 2 \\
\hline \multirow[t]{4}{*}{ Threonine } & 4.59 (d) & $4.48(d)$ & $4.60(d)$ & $4.48(d)$ \\
\hline & $5.21(d)$ & $5.15(d)$ & $5.20(d)$ & $5.16(d)$ \\
\hline & $1.23(\mathrm{~s})$ & $1.23(\mathrm{~s})$ & $1.26(\mathrm{~s})$ & $1.26(\mathrm{~s})$ \\
\hline & $7.13(d)$ & $7.72(d)$ & $7.19(d)$ & $7.81(d)$ \\
\hline \multirow[t]{5}{*}{ Valine } & $3.52(\mathrm{~m})$ & $3.54(\mathrm{~m})$ & $3.54(\mathrm{~m})$ & $3.55(\mathrm{~m})$ \\
\hline & $2.18(\mathrm{~m})$ & $2.02(\mathrm{~m})$ & $2.16(\mathrm{~m})$ & $2.08(\mathrm{~m})$ \\
\hline & $0.97(d)$ & $0.87(d)$ & $0.90(d)$ & $0.89(d)$ \\
\hline & $1.10(d)$ & $1.10(d)$ & $1.12(d)$ & $1.12(d)$ \\
\hline & $8.14(d)$ & 7.98 (d) & $8.09(d)$ & 7.94 (d) \\
\hline \multirow[t]{4}{*}{ Proline } & $5.99(d)$ & $5.93(d)$ & $6.02(d)$ & $5.98(d)$ \\
\hline & $1.88(\mathrm{~m}), 2.67(\mathrm{~m})$ & $1.87(\mathrm{~m}), 2.67(\mathrm{~m})$ & $1.88(\mathrm{~m}), 2.67(\mathrm{~m})$ & $1.87(\mathrm{~m}), 2.67(\mathrm{~m})$ \\
\hline & $2.18(\mathrm{~m})$ & $2.15(\mathrm{~m})$ & $2.17(\mathrm{~m}), 2.25(\mathrm{~m})$ & $2.15(\mathrm{~m}), 2.25(\mathrm{~m})$ \\
\hline & $3.73(\mathrm{~m})$ & $3.93(\mathrm{~m})$ & $3.72(\mathrm{~m})$ & $3.82(\mathrm{~m})$ \\
\hline \multirow[t]{3}{*}{ Sarcosine } & $4.75(d)$ & $4.68(d)$ & $4.76(d)$ & $4.70(d)$ \\
\hline & $3.62(d)$ & $3.64(d)$ & 3.61 (d) & $3.64(d)$ \\
\hline & $2.88(\mathrm{~s})$ & $2.88(\mathrm{~s})$ & $2.88(\mathrm{~s})$ & $2.88(s)$ \\
\hline \multirow[t]{4}{*}{ MethylValine } & $2.68(\mathrm{~m})$ & $2.68(\mathrm{~m})$ & $2.67(\mathrm{~m})$ & $2.67(\mathrm{~m})$ \\
\hline & $0.93(d)$ & $0.86(d)$ & $0.96(d)$ & $0.95(d)$ \\
\hline & $0.72(d)$ & $0.72(d)$ & $0.75(d)$ & $0.75(d)$ \\
\hline & $2.85(\mathrm{~s})$ & $2.91(\mathrm{~s})$ & $2.90(\mathrm{~s})$ & $2.94(\mathrm{~s})$ \\
\hline
\end{tabular}

35984 (MRSE) and methicillin-resistant Staphylococcus aureus ATCC 25923 (MRSA)]. The compound SPE-B11.8 exhibited moderate antibacterial activity with MIC values ranging between $15.63-62.5 \mu \mathrm{g} / \mathrm{ml}$ whereas actinomycin D showed strong activity with MIC values between 0.04$2.24 \mu \mathrm{g} / \mathrm{ml}$ against various test organisms [49]. Wang et al. determined antibacterial activities of actinomycins $\mathrm{X}_{0 \beta}, \mathrm{X}_{2}$ and D purified from Streptomyces heliomycini strain WH1 and demonstrated strong activity of actinomycins $\mathrm{X}_{2}$ and $\mathrm{D}$ against $S$. aureus, methicillin-resistant $S$. aureus, B. subtilis and B. cereus with MIC values of 0.04-0.15 $\mu \mathrm{M}$, whereas act $\mathrm{X}_{0 \beta}$ displayed weak activity with MIC values of $0.3-2.5 \mu \mathrm{M}$ [50]. Recently, Wang et al. evaluated antibacterial activity of actinomycins D, $\mathrm{X}_{2}$, and two new natural neoactinomycins $\mathrm{A}$ and $\mathrm{B}$ against various strains of E. coli, K. pneumoniae, MRSA and VRE. Actinomycins $\mathrm{D}$ and $\mathrm{X}_{2}$ were found to be very effective against MRSA and VRE with MIC values of $0.125-0.25 \mu \mathrm{g} / \mathrm{ml}$, whereas neo-actinomycins A and $B$ showed moderate to weak antibacterial activity with MIC values of $16-64 \mu \mathrm{g} / \mathrm{ml}$ and $128 \mu \mathrm{g} / \mathrm{ml}$, respectively against MRSA and VRE. However, all the actinomycins showed weak activity against different strains of $E$. coli and $K$. pneumoniae with MIC values $>128 \mu \mathrm{g} / \mathrm{ml}$ [51].

In contrast, Kulkarnia et al. demonstrated antifungal activity of actinomycin D purified from an agricultural soil bacterium Streptomyces hydrogenans IB310 against fungal phytopathogens in addition to bacterial cultures which suggests the future application of actinomycin D in agriculture to control fungal plant diseases [52].

Our study demonstrated strong antibacterial activity of actinomycins D, $\mathrm{X}_{2}$ and $\mathrm{V}$ isolated from Streptomyces strain M7 against VRE, MRSA, B. subtilis, K. pneumoniae sub sp. pneumoniae, S. epidermidis, S. typhi, E. coli, S1-LF and S. aureus. The MIC values of actinomycins against VRE were $1.95-2.0 \mu \mathrm{g} / \mathrm{ml}$, which are higher than those reported in earlier studies [49-51]. However, actinomycins were found to be more effective against $E$. coli and $K$. pneumoniae (MIC values $15.65-64 \mu \mathrm{g} / \mathrm{ml}$ ) as compared to actinomycins D and $\mathrm{X}_{2}(>128 \mu \mathrm{g} / \mathrm{ml})$ reported by Wang et al. [51]. The findings of the present investigation also support the extended application of 


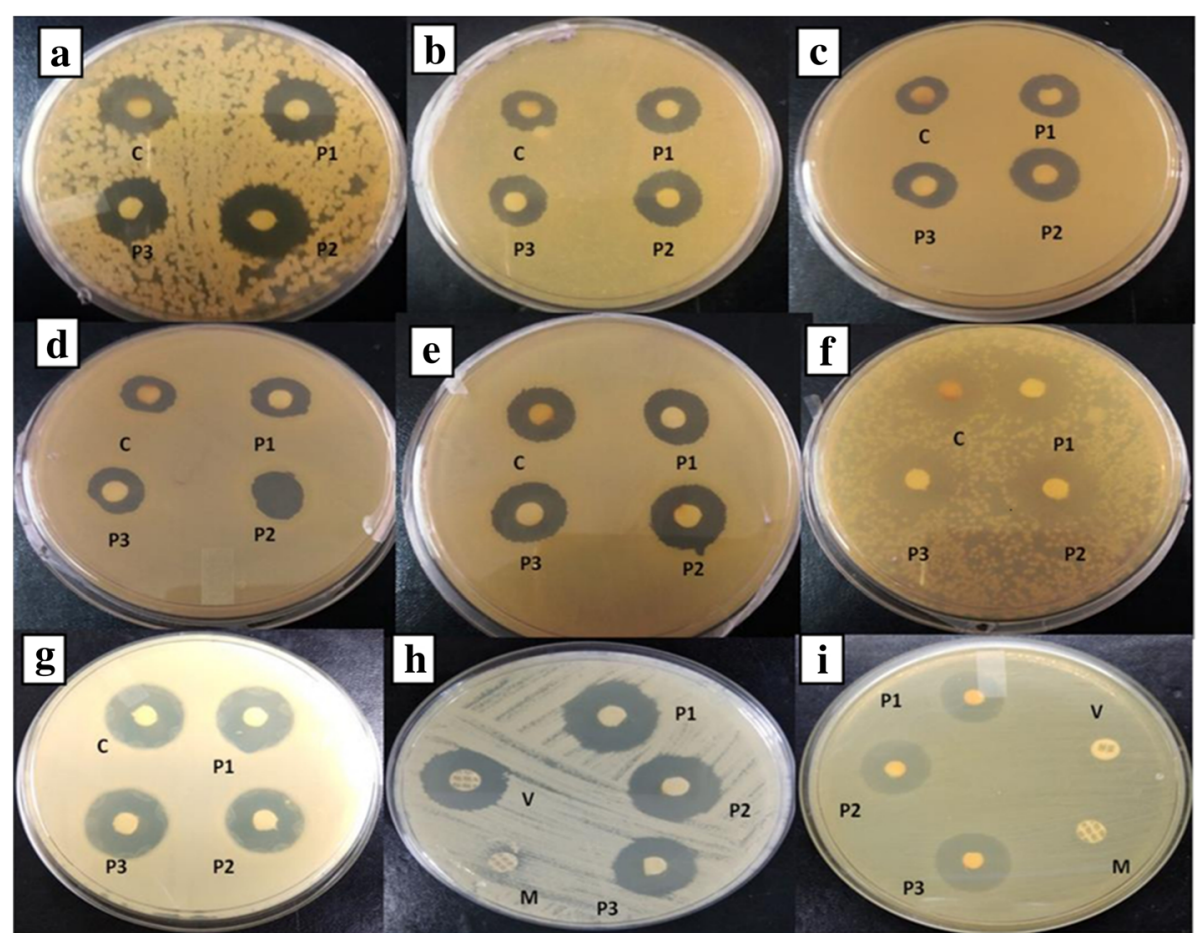

Fig. 6 Antibacterial activity of Streptomyces strain M7 against pathogenic bacteria: (a) Staphylococcus epidermidis (b) Salmonella typhi (c) Bacillus subtilis (d) Klebsiella pneumoniae sub sp. pneumoniae (e) Staphylococcus aureus (f) E. coli (g) S1LF (h) MRSA (i)VRE.C: crude extract, P1: Actinomycin

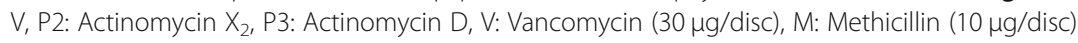

actinomycins to treat bacterial infections caused by drug resistant bacteria, especially methicillin-resistant $S$. aureus and vancomycin resistant Enterococcus.

\section{Conclusions}

The results of the present study reveal the potential of actinomycins $\mathrm{V}, \mathrm{X}_{2}$ and $\mathrm{D}$, which are generally used as anticancer drugs, to treat nosocomial infections caused by various bacteria viz. K. pneumoniae sub sp. pneumoniae, S. epidermidis, S. typhi, E. coli, S1-LF, S. aureus, MRSA and VRE.

\section{Additional files}

Additional file 1: Table S1 Cultural characteristics of Streptomyces antibioticus strain M7 on different media. Table S2 Antibacterial activity of purified compounds. Table S3 MIC of purified compounds. (DOCX $17 \mathrm{~kb}$ )

Additional file 2: Figure S1 HPLC chromatogram of purified compounds from S. antibioticus strain M7: (a) fractions (27-35), b) mixture of compounds $\mathrm{P} 2$ and $\mathrm{P} 3$, (c) compound $\mathrm{P} 1$, (d) compound $\mathrm{P} 2$, (e) compound P3. 1: Compound P1, 2: Compound P2, 3: Compound P3. Figure S2 (a) Thin layer chromatography of Streptomyces M7 crude extract (c), mixture of purified compounds $(M)$ and purified compounds (P). (b) Bioautography of purified compounds of S. antibioticus strain M7 against $B$. subtilis. Figure S3 FT-IR Spectrum of purified compounds (a) Actinomycin V (P1), (b) Actinomycin $X_{2}(P 2)$, (c) Actinomycin D (P3). (DOCX $1971 \mathrm{~kb}$ )

Additional file 3: Figure S4 (a-d): ${ }^{1} \mathrm{H}$ NMR spectra of purified Actinomycin V (P1). Figure S5 (a-f): ${ }^{1} H$ NMR spectra of purified
Actinomycin $X_{2}(P 2)$. Figure $\mathbf{S 6}(\mathbf{a}-\mathbf{g}):{ }^{1} H$ NMR spectra of purified Actinomycin D (P3). (DOCX 1407 kb)

\section{Abbreviations}

DAP: Diaminopimelic acid; FT-IR: Fourier transformation infrared spectroscopy; ISP: International Streptomyces Project; MHA: Mueller Hinton Agar; MIC: Minimum inhibitory concentration; MRSA: Methicillin resistant Staphylococcus aureus; MS: Mass spectrometry; MTCC: Microbial type culture collection; NMR: Nuclear magnetic resonance; SCNA: Starch Casein Nitrate Agar; VRE: Vancomycin resistant Enterococcus

\section{Acknowledgements}

One of the authors, Manish Sharma acknowledges the grant of fellowship under UPE (University with Potential for Excellence) scheme of University Grants Commission, New Delhi, India.

\section{Funding}

This work was financially supported by University Grant Commission, New Delhi (Letter No. F. No. 43-468/2014(SR) dated 24/9/15.

\section{Availability of data and materials}

All data generated or analysed during this study are included in this published article and additional supplementary files.

\section{Authors' contributions}

RM as research supervisor of MS was involved in the design and planning of research work; analysis and interpretation of data; drafting as well as critical editing of the manuscript for intellectual subject matter. MS was involved in the planning and execution of the research work; analysis and interpretation of the data; manuscript writing following the suggestions of the research supervisor. All authors have read and approved the manuscript.

Ethics approval and consent to participate Not Applicable. 


\section{Consent for publication}

Not applicable.

\section{Competing interests}

The authors declare that they have no competing interests.

\section{Publisher's Note}

Springer Nature remains neutral with regard to jurisdictional claims in published maps and institutional affiliations.

\section{Received: 10 February 2018 Accepted: 29 January 2019} Published online: 19 February 2019

\section{References}

1. Laxminarayan R, Matsoso P, Pant S, Brower C, Rottingen JA, Klugman K, Davies S. Access to effective antimicrobials: a worldwide challenge. Lancet. 2016:387(10014):168-75.

2. Jevons MP. "Celbenin"-resistant Staphylococci. Br Med J. 1961;1:124-5.

3. Boucher HW, Corey GR. Epidemiology of methicillin-resistant Staphylococcus aureus. Clin Infect Diseas. 2008:1(46(Supplement_5)):S344-9.

4. Chen SY, Wang JL, Chen TH, Chiang WC, Wang JT, Chen SC, Chang PR. Differences between methicillin-resistant Staphylococcus aureus bacteremic isolates harboring type IV and type V staphylococcal cassette chromosome mec genes based on prior patient healthcare exposure. Eur J Clin Microbiol Infect Dis. 2010;29(12):1539-46

5. Van Hal SJ, Jensen SO, Vaska VL, Espedido BA, Paterson DL, Gosbell IB. Predictors of mortality in Staphylococcus aureus bacteremia. Clin Microbiol Rev. 2012;25(2):362-86.

6. Arias CA, Murray BE. The rise of the Enterococcus: beyond vancomycin resistance. Nat Rev Microbiol. 2012;10(4):266-78.

7. Rossolini GM, Arena F, Pecile P, Pollini S. Update on the antibiotic resistance crisis. Clin Opin Pharmacol. 2014;18:56-60

8. Hiramatsu K, Aritaka N, Hanaki H, Kawasaki S, Hosoda Y, Hori S, Fukuchi Y, Kobayashi I. Dissemination in Japanese hospitals of strains of Staphylococcus aureus heterogeneously resistant to vancomycin. Lancet. 1997;350(9092): 1670-3.

9. Centers for Disease Control and Prevention, Office of Infectious Disease United States, 2013. Antibiotic resistance threats in the United States, 2013. https:// www.cdc.gov/drugresistance/about.html.

10. Hirschwerk D, Ginocchio CC, Bythrow M, Condon S. Diminished susceptibility to daptomycin accompanied by clinical failure in a patient with methicillin-resistant Staphylococcus aureus bacteremia. Infect Control Hosp Epidemiol. 2006;27(3):315-7

11. Appelbaum PC. Reduced glycopeptide susceptibility in methicillin-resistant Staphylococcus aureus (MRSA). Int J Antimicrob Agents. 2007;30(5):398-408.

12. Sharma M, Riederer $K$, Chase $P$, Khatib R. High rate of decreasing daptomycin susceptibility during the treatment of persistent Staphylococcus aureus bacteremia. Eur J Clin Microbiol Infect Dis. 2008;27(6):433-7.

13. Moore CL, Osaki-Kiyan P, Haque NZ, Perri MB, Donabedian S, Zervos MJ. Daptomycin versus vancomycin for bloodstream infections due to methicillin-resistant Staphylococcus aureus with a high vancomycin minimum inhibitory concentration: a case-control study. Clin Infect Dis. 2012:54(1):51-8

14. Watve MG, Tickoo R, Jog MM, Bhole BD. How many antibiotics are produced by the genus Streptomyces? Arch Microbiol. 2001;176(5):386-90.

15. Kim OS, Cho YJ, Lee K, Yoon SH, Kim M, Na H, Park SC, Jeon YS, Lee JH, Yi $\mathrm{H}$, Won S, Chun J. Introducing EzTaxon-e: a prokaryotic $16 \mathrm{~S}$ rRNA gene sequence database with phylotypes that represent uncultured species. Int J Syst Evol Microbiol. 2012;62(3):716-21.

16. Kumar P, Preetam RJ, Duraipandiyan V, Ignacimuthu S. Antibacterial activity of some actinomycetes from Tamil Nadu, India. Asian Pac J Trop Biomed. 2012;2:936-43.

17. Mohanraj G, Sekar T. Isolation and screening of actinomycete from marine sediments for their potential to produce antimicrobials. Int J Life Sci Pharma Res. 2013;2(12):115-26

18. Newman DJ, Cragg GM, Snader KM. Natural products as sources of new drugs over the period 1981-2002. J Nat Prod. 2003;66(7):1022-37.

19. Bauer AW, Kirby WMM, Sherris JC, Turck M. Antibiotics susceptibility testing by a standardized single disc method. Am J Clin Patho. 1966;45(4):493-6.

20. Shirling EB, Gotllieb D. Methods for characterization of streptomycetes sp. Int J Syst Bacteriol. 1966;16:313-40.
21. Anderson AS, Wellington EM. The taxonomy of Streptomyces and related genera. Int J Syst Evol Microbiol. 2001;51(3):797-814.

22. Cowan ST, Steel KJ. Manual for the identification of medical Bacteria. London: Cambridge University Press; 1965.

23. Lanyi B. Classical and rapid identification methods for medically important bacteria. Methods Microbiol. 1987;19:1-67.

24. Smibert RM, Krieg NR. Phenotypic characterization. In: Gerhardt P, Murry RGE, Wood WA, Krieg NR, editors. Methods for general and molecular bacteriology, Washington DC: American Society of Microbiology; 1994. p. 607-54.

25. Lechevalier MPA, Lechevalier HA. The chemotaxonomy of actinomycetes. In: Dietz A, Thayer DW, editors. Actinomycetes taxonomy. Arlington: Society for Industrial Microbiology; 1980. p. 22-291.

26. Marmur J. A procedure for the isolation of deoxyribonucleic acid from microorganisms. J Mol Biol. 1961:3:208-18.

27. Lane DJ. 16S/23S rRNA sequencing. In: Stackebrandt E, Goodfellow M, editors. Nucleic acid techniques in bacterial systematics. New York: John Wiley and Sons; 1991. p. 115-75.

28. Saitou N, Nei M. The neighbour-joining method: a new method for reconstructing phylogenetic trees. Mol Biol Evol. 1987;4:406-25.

29. Tamura K, Stecher G, Peterson D, Filipski A, Kumar S. MEGA6: molecular evolutionary genetics analysis version 6.0. Mol Biol Evol. 2013;28:2731-9.

30. Lehman JW. Operational Organic Chemistry: A Problem Solving Approach to the Laboratory Course. 3rd ed. Upper Saddl River, NJ: Prentice Hall; 1999.

31. Booth H, Mauger AB, Rzeszotarski WJ. A 13C NMR study of actinomycin D and related model peptides. Org Magn Reson. 1976;8(4):219-23.

32. Hamza AA, Ali HA, Clark BR, Murphy CD, Elobaid EA. Isolation and characterization of actinomycin D producing Streptomyces spp. from Sudanese soil. Afr J Biotechnol. 2013;12(19):2624-32.

33. Díaz-Dellavalle $P$, Cabrera A, Alem D, Larrañaga P, Ferreira F, Dalla-Rizza M. Antifungal activity of medicinal plant extracts against phytopathogenic fungus Alternaria spp. Chilean J Agric Res. 2011;71:231-9.

34. Wright GD. Q\&A: antibiotic resistance: where does it come from and what can we do about it? BMC Biol. 2010;8;123.

35. Gould IM, David MZ, Esposito S, Garau J, Lina G, Mazzei T, Peters G. New insights into methicillin-resistant Staphylococcus aureus MRSA: pathogenesis, treatment and resistance. Int J Antimicrob Agents. 2012:39(2):96-104.

36. Berglund B. Environmental dissemination of antibiotic resistance genes and correlation to anthropogenic contamination with antibiotics. Inf Ecol Epidemiol. 2015;5:28564.

37. Ventola VC. The Antibiotic Resistance Crisis Part 1: Causes and Threats. Pharmacol Ther. 2015:40(4):277-83.

38. Praveen $V$, Tripathi CK. Studies on the production of actinomycin-D by Streptomyces griseoruber- a novel source. Lett Appl Microbiol. 2009;49(4): 450-55

39. Singh V, Khan M, Khan SA, Tripathi CKM. Optimization of actinomycin V production by Streptomyces triostinicus using artificial neural network and genetic algorithm. Appl Microbiol Biotechnol. 2009;82(2):379-85.

40. Kurosawa K, Bui VP, VanEssendelft JL, Willis LB, Lessard PA, Ghiviriga I, Sambandan TG, Rha CK, Sinskey AJ. Characterization of Streptomyces MITKK103, a newly isolated actinomycin X-2 producer. Appl Microbiol Biotechnol. 2006:72(1):145-54

41. Xiong ZQ, Zhang ZP, Li JH, Wei SJ, Tua GQ. Characterization of Streptomyces padanus JAU4234, a producer of actinomycin X2, fungichromin, and a new polyene macrolide antibiotic. Appl Environ Microbiol. 2012;78:589-92.

42. Elnaggar MYM, Elaassar SA, Hashem MA, Stoodley RJ, Raynor CM, Sigee DC. Production of actinomycin X2 by immobilized Streptomyces nasri YG62 mycelia. Microbios. 1998;95:165-79.

43. Ajijur RMD, Zahidul IMD, Khondkar P, Anwar UIMD. Characterization and antimicrobial activities of a polypeptide antibiotic isolated from a new strain of Streptomyces parvulus. Bangladesh Pharm J. 2010:13:14-6.

44. Shetty PR, Buddana SK, Tatipamula VB, Naga YW, Ahmad J. Production of polypeptide antibiotic from Streptomyces parvulus and its antibacterial activity. Braz J Microbiol. 2014;45(1):303-12.

45. Praveen V, Tripathi CK, Bihari V, Srivastava SC. Production of actinomycin D by the mutant of a new isolate of Streptomyces sindenensis. Braz J Microbiol. 2008:39(4):689-92

46. Wei Z, Xu C, Wang J, Lu F, Bie X, Lu Z. Identification and characterization of Streptomyces flavogriseus NJ-4 as a novel producer of actinomycin D and holomycin. Peer J. 2017;5:e3601. 
47. Bird CW, Latif M. Antibiotics from a newly isolated S. elizabethii II Isolation and characterization of antibiotics. J Chem Technol Biotechnol. 1981;31(1): 368-70.

48. Chen C, Song F, Wang Q, Abdel-Mageed WM, Guo H, Fu C, Hou W, Dai H, Liu X, Yang N, Xie F, Yu K, Chen R, Zhang L. A marine-derived Streptomyces sp. MS449 produces high yield of actinomycin X2 and actinomycin D with potent anti-tuberculosis activity. Appl Microbiol Biotechnol. 2012;95(4):91927.

49. Khieu TN, Liu MN, Nimaichand S, Quach NT, Chu-Ky S, Phi QT, Vu TT, Nguyen TD, Xiong Z, Prabhu DM, Lil WJ. Characterization and evaluation of antimicrobial and cytotoxic effects of Streptomyces sp. HUST012 isolated from medicinal plant Dracaena cochinchinensis Lour. Front Microbiol. 2015;6: 574.

50. Wang D, Wang C, Gui P, Liu H, Khalaf SMH, Elsayed EA, Wadaan MAM, Hozzein WN, Zhu W. Identification, Bioactivity, and Productivity of Actinomycins from the Marine-Derived Streptomyces heliomycini. Front Microbiol. 2017;8:1147.

51. Wang Q, Zhang Y, Wang M, Tan Y, Hu X, He H, Xiao C, You X, Wang Y, Gan M. Neo-actinomycins a and $B$, natural actinomycins bearing the $5 \mathrm{H}$-oxazolo [4,5-b] phenoxazine chromophore, from the marine derived Streptomyces sp. IMB094. Sci Rep. 2017;7:3591.

52. Kulkarnia M, Gorthia S, Banerjee G, Chattopadhyay P. Production, characterization and optimization of actinomycin D from Streptomyces hydrogenans IB310, an antagonistic bacterium against phytopathogens. Biocatal Agric Biotechnol. 2017;10:69-74.

Ready to submit your research? Choose BMC and benefit from:

- fast, convenient online submission

- thorough peer review by experienced researchers in your field

- rapid publication on acceptance

- support for research data, including large and complex data types

- gold Open Access which fosters wider collaboration and increased citations

- maximum visibility for your research: over $100 \mathrm{M}$ website views per year

At $\mathrm{BMC}$, research is always in progress.

Learn more biomedcentral.com/submissions 